\title{
Earth-air heat exchanger as a green retrofit for Chandigarh-a critical review
}

\author{
Jaskiran Sobti ${ }^{2}$ and Sanjay Kumar Singh ${ }^{1 *}$
}

\author{
* Correspondence: sksingh@pec.ac.in \\ ${ }^{1}$ PEC University of Technology, \\ Chandīgarh, India \\ Full list of author information is \\ available at the end of the article
}

\begin{abstract}
The natural resources of the Earth are being exploited beyond its sustainable capacity. The building industry consumes nearly $40 \%$ of the global energy requirement. A major portion of this is used in meeting air-conditioning requirements. The present scenario demands increased energy efficiency, i.e., indoor thermal comfort with minimal energy consumption in buildings. Thus, the development of new green technologies, which allows the use of sustainable alternative sources of energy, is the need of the hour. Earth-air heat exchangers (EAHE), which make use of a passive means for the heating and cooling of buildings, are becoming a promising technology in the construction of green buildings. EAHE utilizes the thermal energy contained in the soil at certain depths for meeting the cooling/heating requirement of buildings, reducing the consumption of conventional energy for built environments. The present paper addresses issues of applicability of EAHE in Chandīgarh (India) based upon literature review particularly in Indian context and keeping in mind the nature of soil and climatic conditions of the city.
\end{abstract}

Keywords: Green buildings; Earth-air heat exchangers; Thermal comfort; Thermal conductivity; Specific heat

\section{Review}

Introduction

Buildings contribute over $40 \%$ of the total global primary energy use corresponding to $24 \%$ of the $\mathrm{CO}_{2}$ emissions of the world (IEA 2008). Building heating, ventilation, and air-conditioning (HVAC) systems are responsible for about half of the energy use in buildings (Perez-Lombard et al. 2008). Construction of new buildings provide an opportunity to limit the use of existing conventional practices and adopt energy efficient design and implementation of green technologies. Effective application of passive features in the building design can significantly minimize the air-conditioning demand in buildings while maintaining thermal comfort (Santamouris et al. 1995).

The nearly constant ground temperature at a certain depth has been regarded as a passive means for the heating and cooling of buildings by several researchers (Goswami and Dhaliwal 1985; Mihalakakou 1997; Paepe and Janssens 2002; Ozgener et al. 2013). It has been observed that the ground temperature at a depth of about 1.5 to $2 \mathrm{~m}$ remains constant throughout the year and is equal to the annual average temperature of a particular place (Kusuda 1975; Bhardwaj and Bansal 1981; Jacovides et al. 1996; Bisoniya et al. 2013; Bisoniya et al. 2014; Ghosal and Tiwari 2004). This 
constant temperature remains lower than the ambient air temperature in summer and higher in winter. The earth-air heat exchangers (EAHE) is basically a series of pipes buried underground at a particular depth through which fresh atmospheric air flows and gets cooled in summer and warmed in winter. This paper addresses issues of applicability of EAHE in Chandīgarh (India) based upon literature review particularly in Indian context and keeping in mind the nature of soil and climatic conditions of the city.

\section{Earth-air heat exchangers (EAHE)}

The basic principle of EAHE is that of several pipes buried in the ground with one end of the pipe system acting as an inlet for fresh atmospheric air as shown in Fig. 1. The ambient air traveling through the pipes exchanges heat with the pipe walls which are in contact with the surrounding underground environment, transferring heat through conduction and convection processes. The other end acting as an outlet releases air to the interior of a building. The performance of EAHE is directly related to the thermal properties of the ground and the heat transfer between the pipes and the ground (Mihalakakou et al. 1995; Mihalakakou 1997). The heat transfer mechanisms in soil are conduction, convection, and radiation. Conduction occurs throughout the soil, but the main flow of heat is through the solid and liquid constituents. Convection is usually negligible, with the exception of rapid water infiltration after heavy rainfall. Radiation is important only in very dry soils, with large pores, when the temperature is high. Therefore, the main parameters influencing the thermal behavior of the soil are thermal conductivity and heat capacity that are jointly expressed in terms of thermal diffusivity below:

$$
\alpha=\frac{k}{\rho \varsigma}
$$

where $k$ is the thermal conductivity, $\rho$ is the density, and $\varsigma$ is the specific heat of the soil. The amount of heat exchanged between the air and the surrounding soil depends upon various parameters, e. g., surface area of the pipes, length of the pipes, water contents of the inlet air and dampness of the earth, temperature of the earth, air velocity, material and surface conditions of the pipes, depth of the pipes from the ground surface, soil type etc. (Kumar et al. 2006).

The EAHE find its application in greenhouses, commercial, and residential buildings for space conditioning. The depth at which they are installed has vital importance on

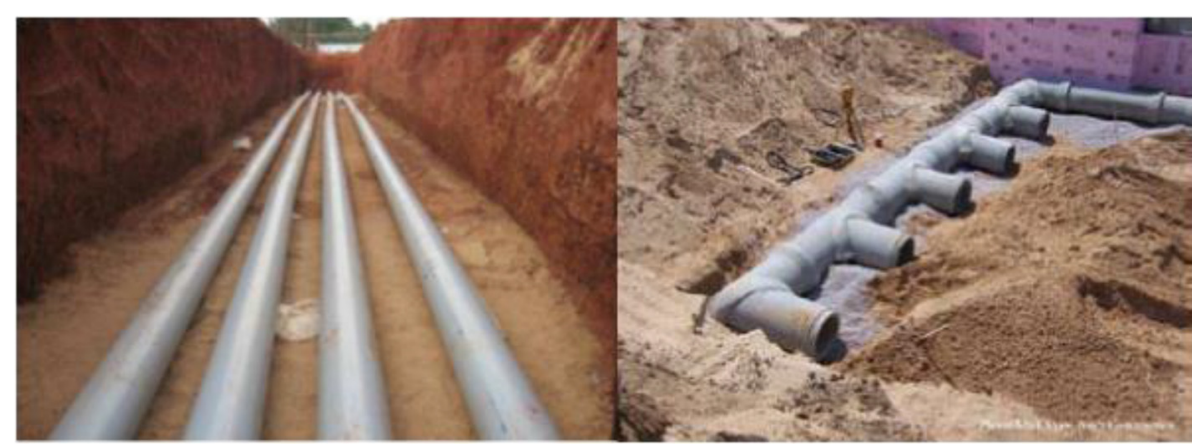

Fig. 1 Pictorial representation of the EAHE system 
dimensions, performance, and installation costs of the system (Ozgener 2011; Ozgener and Ozgener 2010, 2011). The material of the pipes may be mild steel, cement, or PVC, depending on the location of the water table. The use of EAHE can lead to a reduction of high-grade energy consumption. They have high capital costs, but over the lifespan of the system, EAHE can yield substantial savings. The efficiency of the EAHE system can be judged by an energy analysis of the system. The energy parameters to be evaluated include energy payback time (EPBT) and seasonal energy efficiency ratio (SEER) etc. The number of years required to recover energy invested, i.e., in manufacturing, transportation, installation, operation, and maintenance of the system while in use, is called EPBT. EPBT can be defined as ratio of embodied energy of the EAHE system $(\mathrm{kWh})$ to total yearly energy output of the EAHE system $(\mathrm{kWh})$. The seasonal energy efficiency ratio (SEER) is the measure of the heating/cooling efficiency of heat pump/air conditioners. The value of SEER is determined by dividing the total monthly heat-energy gain/loss (in winter/summer, respectively) from the room air by the total monthly energy consumed by the EAHE. The SEER value is always desired to be more than one for EAHE to be economically viable (Chel and Tiwari 2009).

\section{Climatic conditions of Chandīgarh}

The Union Territory of Chandigarh (latitude $30.74^{\circ} \mathrm{N}$, longitude $76.79^{\circ} \mathrm{E}$, and altitude $321 \mathrm{~m}$ ) is located in the foothills of the Shivalik hill range in the north, which form a part of the fragile Himalayan ecosystem. It covers an area of approximately $114 \mathrm{sq} . \mathrm{km}$. It shares its borders with the sates of Haryana in the east and Punjab in the north, west, and south. Chandigarh has a humid sub-tropical climate characterized by very hot summers, mild winters, unreliable rainfall, and a great variation in temperature (winter minimum $1-16{ }^{\circ} \mathrm{C}$, summer maximum $27-44{ }^{\circ} \mathrm{C}$ ). The average rainfall is $1110.7 \mathrm{~mm}$. (Official website of the Chandigarh Administration (2015)). The city also receives occasional winter rains from the west. It can be observed from Figs. 2 and 3 depicting average monthly maximum and minimum temperatures, respectively, that Chandīgarh requires cooling from April to October

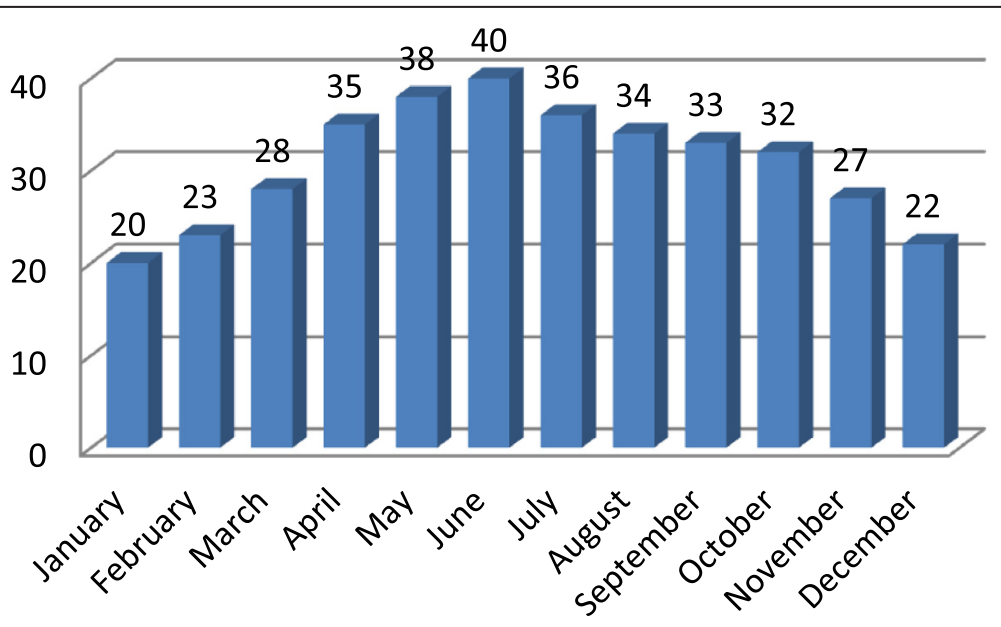

Average monthly maximum temperature ${ }^{\circ} \mathrm{C}$

Fig. 2 Average monthly maximum temperature 


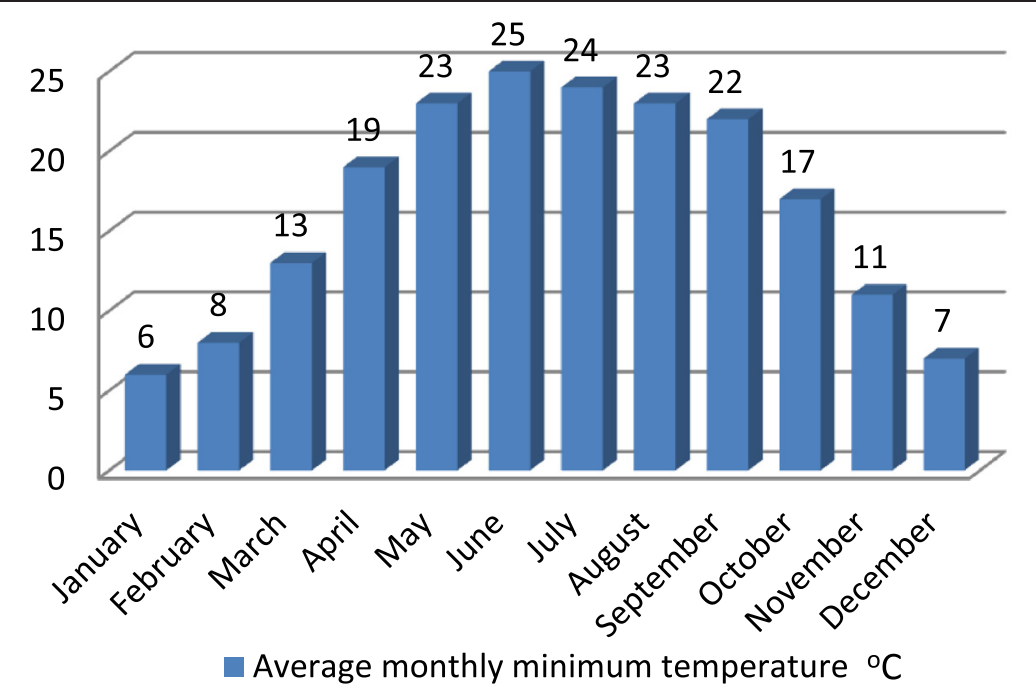

Fig. 3 Average monthly minimum temperature

and heating in the months from October to April, the coinciding months having relatively bearable weather.

\section{Orientation of buildings}

Chandigarh is a well-planned city, designed by the famous French architect Le Corbusier and also, known as The City Beautiful. At that time, it was kept in mind to orient the buildings of city in order to derive maximum benefits from the prevailing winds and the direction of the Sun. Looking at the wind-incidence profile in Fig. 4 for Chandigarh, it is observed that the city gets the majority of its wind from the north-northeast. This is primarily due to the fact that most of the wind is deflected from the Pir Panjal range and then received by the city. Therefore, a north-south to northeast-southwest orientation of

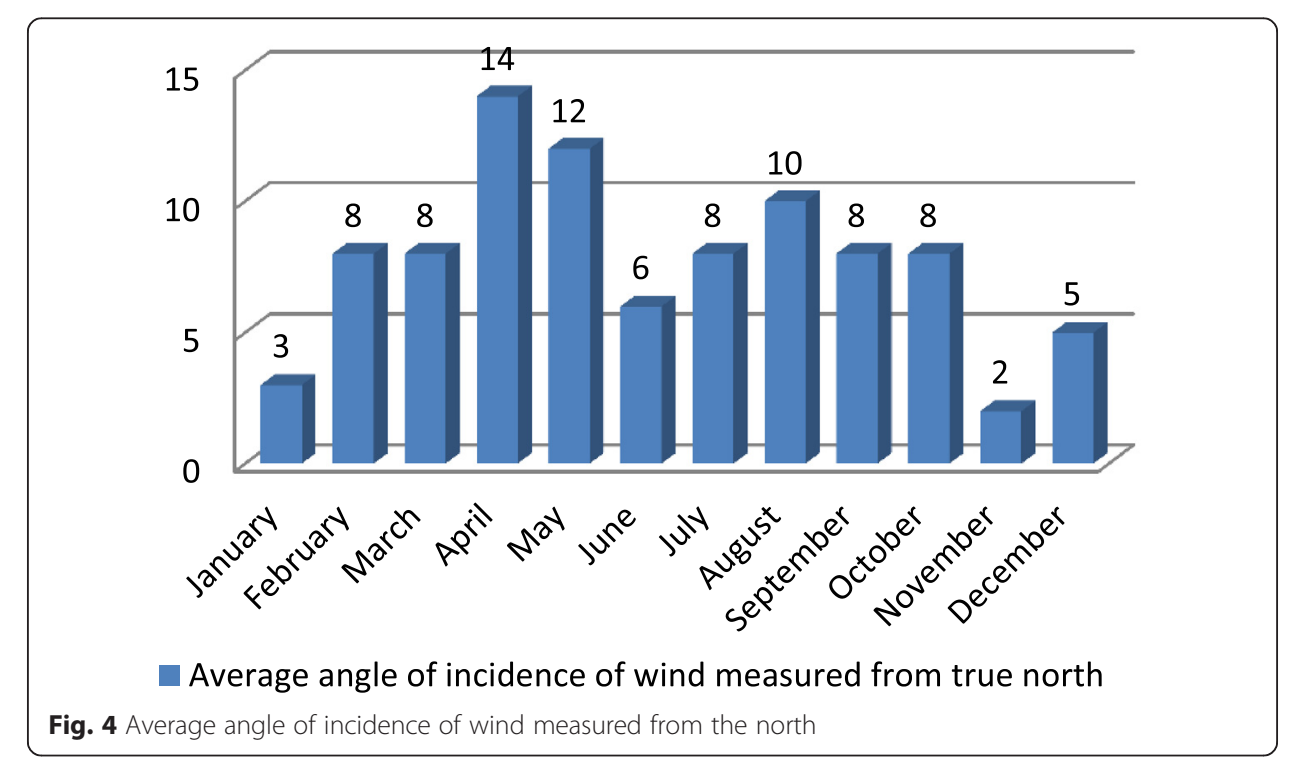


the buildings is ideal, considering the added advantage of minimizing the amount of solar radiation that the buildings receive, thus keeping the interiors of the buildings cool. As a matter of fact, the majority of office buildings in Chandigarh are oriented along the north-south to northeast-southwest direction.

\section{Sub-surface soil and ground water characteristics in Chandīgarh}

Chandiggarh (UT) has two satellite towns, i.e., Mohali (Punjab) and Panchkula (Haryana), combined they are known as Tricity. Considering the soil type of the Tricity, in Chandigarh, sandy silt is observed up to a depth of $3 \mathrm{~m}$ with the water table at 5-15 m below ground level. In Mohali, clayey silt is observed up to a depth of $3 \mathrm{~m}$ with the water table at a depth of 3-5 m below ground level, while in Panchkula, the soil is silty sand with clay and gravel with the ground water table up to a depth of 10-12 m (DMRC 2012).

The determination of soil thermal properties, such as thermal resistivity, thermal conductivity, thermal diffusivity, and specific heat is of great importance for installation of EAHE systems, where heat transfer takes place through the soil mass.

The amount of heat conducted and how widely it is diffused varies from one soil to another depending upon its diffusivity as given in Table 1.

\section{Applicability of EAHE in Chandīgarh}

In sub-tropical climates like India, the electricity demand during peak season of summer and winter goes up due to operation of air-conditioning devices in buildings resulting in a wide gap between demand and supply. Developing countries

Table 1 Thermal properties of selected soil (ASHRAE, 2000)

\begin{tabular}{llll}
\hline & Dry density, $\mathrm{kg} / \mathrm{m}^{3}$ & Conductivity, W/(m K) & Diffusivity, $\mathrm{m}^{2} /$ day \\
\hline Soils & & & \\
Heavy clay (15\% water) & 1925 & $1.4-1.9$ & $0.042-0.061$ \\
Heavy clay (5\% water) & 1925 & $1.0-1.4$ & $0.047-0.061$ \\
Light clay (15\% water) & 1285 & $0.7-1.0$ & $0.055-0.047$ \\
Light clay (5\% water) & 1285 & $0.5-0.9$ & $0.056-0.056$ \\
Heavy sand (15\% water) & 1925 & $2.8-3.8$ & $0.084-0.11$ \\
Heavy sand (5\% water) & 1925 & $2.1-2.3$ & $0.093-0.14$ \\
Light sand (15\% water) & 1285 & $1.0-2.1$ & $0.047-0.093$ \\
Light sand (5\% water) & 1285 & $0.9-1.9$ & $0.055-0.12$ \\
Rocks & & & \\
Granite & 2650 & $2.3-3.7$ & $0.084-0.13$ \\
Limestone & $2400-2800$ & $2.4-3.8$ & $0.084-0.13$ \\
Sandstone & $2570-2730$ & $2.1-3.5$ & $0.65-0.11$ \\
Wet shale & & $1.4-2.4$ & $0.065-0.084$ \\
Dry shale & & $1.0-2.1$ & $0.055-0.074$ \\
Grouts/backfills & & & \\
Bentonite (20 \% solids) & & $0.73-0.75$ & \\
Cement & & $0.70-0.78$ & \\
20 \% bentonite $-40 \% \mathrm{SiO}_{2}$ sand & & 1.48 & \\
Concrete (50 \% SiO ${ }_{2}$ sand) & & $2.1-2.8$ & \\
\hline
\end{tabular}


like India continue to experience energy as well as peak power shortages of varying magnitude. It is estimated that demand of electricity in Chandigarh during peak season is $350 \mathrm{MW}$, but the availability is only $324 \mathrm{MW}$ (CEA 2014). This gap between demand and supply could be easily bridged with the application of EAHE systems in buildings. The effectiveness of the EAHE system depends on the climatic conditions of the city, thermal conductivity of soil, type of soil, temperature, position of the water table etc.

The soil type of Chandigarh is light to heavy sand as described in Table 1, for which the diffusivity varies from 0.084 to $0.14 \mathrm{~m}^{2} /$ day, which is greater than other soil types. Therefore, the EAHE systems would be quite suitable in Chandigarh. Also, thermal conductivity of soil increases with increase in moisture content, and the correlation could be linear or nonlinear (Sugathan et al. 2014). The natural moisture content of soils in the Tricity varies from 10-15\%. The better the conductivity of soil, the better is the performance of EAHE. Efficacy of EAHE in Chandigarh can be further corroborated with experimental results taken from studies carried out in various parts of India (Ahmedabad, Ajmer, Bhopal and New Delhi), which possess more or less similar climatic and soil conditions as Chandigarh.

Sharan and Jadhav $(2002,2003)$ conducted an experimental study in Ahmedabad for determining the efficiency of EAHE to cool the air in summer and warm it up in winter. The location had a climatic profile close to Chandigarh and a sandy silt soil type (sand $48 \%$, silt $41 \%$, clay $11 \%$ ) and moisture content was $12.61 \%$, very close to that of soil in Chandigarh. For this, a pilot test was carried out for a 50-m long; 10-cm diameter mild steel pipe with wall thickness of $3 \mathrm{~mm}$, placed at a depth of $3 \mathrm{~m}$. The air was moved at $11 \mathrm{~m} / \mathrm{s}$ through the pipe. It was observed that EAHE caused a drop of $14{ }^{\circ} \mathrm{C}$ in the summer months and an appreciable rise in the winter months in the circulated air. The temperature range and ground temperature closely follows that of Chandigarh except that the rains occur a while before in Chandigarh, but in every other sense, Ahmedabad's climate is comparable to that of Chandigarh.

Bansal et al. $(2009,2010)$ carried out a performance analysis of earth-air heat exchangers (EAHE) systems for winter heating and summer cooling in the city of Ajmer (India). A transient model based on computational fluid dynamics (CFD) was developed to predict the thermal performance of earth-air heat exchanger systems. The results were validated by conducting an experimental study on the model setup in Ajmer city. The setup consisted of two horizontal cylindrical pipes of 0.15-m inner diameter, 23.42-m long, made up of PVC and mild steel and buried at a depth of $2.7 \mathrm{~m}$ in the ground. The EAHE system gave a temperature rise of $4.1-4.8{ }^{\circ} \mathrm{C}$ in winter and cooling in the range of $8.0-12.7{ }^{\circ} \mathrm{C}$ in summer for the flow velocity ranging from 2 to $5 \mathrm{~m} / \mathrm{s}$. Also, performance of a EAHE can be enhanced by integrating an evaporative cooler at the outlet and a solar air-heating duct at the exit end during the summer and winter season, respectively. Results show that an EAHE system alone provides $4500 \mathrm{MJ}$ of cooling effect during summers, whereas 3109 MJ of additional cooling effect can be achieved by integrating an evaporative cooler with the EAHE (Bansal et al. 2012). It was found that the heating capacity of the EAHE system was increased by 1217-1280 kWh when it was coupled with a solar air-heating duct with a substantial increase in room temperature by $1.1-3.5{ }^{\circ} \mathrm{C}$. The coefficient of performance (COP) of the 
system also increased up to 4.57 with the provision of a solar air-heating duct (Jakhar et al. 2015).

Chel and Tiwari (2009) analyzed a computer-based thermal model to predict the energy-saving potential of an adobe house with a vault roof structure integrated with an EAHE for space heating and cooling in New Delhi, India. The results from the thermal model were validated from the experimentally observed data. Experimental results showed that the room air temperature during winter was found $5-15{ }^{\circ} \mathrm{C}$ higher as compared to ambient air temperature while lower during summer months. It was found that the energy payback time is less than 2 years for the investment in EAHE system. The seasonal energy efficiency ratio (SEER) for EAHE was determined as 2-3.

Bisoniya et al. (2015) carried out a study to evaluate the annual thermal performance of the EAHE system for hot and dry climatic conditions of Bhopal (Central India). A 3D model based on computational fluid dynamics (CFD) was developed with specified dimensions (length of buried pipe $19.228 \mathrm{~m}$, diameter of pipe $0.1016 \mathrm{~m}$, and depth of burial $2 \mathrm{~m}$ ) to evaluate the heating and cooling potential of the EAHE system, with airflow velocities of $2,3.5$, and $5 \mathrm{~m} / \mathrm{s}$. The simulation results were validated against experimental observations from an experimental setup installed in Bhopal. The energy metrics, namely energy payback time (EPBT) and seasonal energy efficiency ratio (SEER) for the EAHE system, were evaluated on the basis of energy analysis of simulation results. The EPBT of the EAHE system was calculated as 1.29 years. The SEER for typical summer and winter months were calculated as 1.34 and 1.10 , respectively.

Although this is only an empirical comparison, the technology shows promise for cities with similar climates and can be used to a great effect in Chandigarh. It was observed that the effectiveness of EAHE declines with the advent of monsoons. Rains not only make it harder to cool air, but also pose problems of condensation within the pipes, threatening to block them. Therefore, in Chandigarh, EAHE can be used effectively from October end to mid-June, i.e., from monsoon ending to monsoon starting. When humidity starts to peak, EAHE can be used along with conventional cooling systems.

As for the materials used in EAHE construction for the pipes, the best materials that can be used are steel pipes, as they have the highest thermal conductivity and lowest specific heat, and as a result, it transfers heat from air to earth and vice-versa the quickest as illustrated in Table 2.

However, they can corrode easily. In regions where the water table is high, steel pipes may corrode over time, leading to cracks and subsequently infiltration of ground water into the pipes. In Chandigarh, where the water table is well below $3 \mathrm{~m}$ throughout the year, steel pipes prove to be the most effective material for the EAHE.

Table 2 Thermal properties of pipe materials

\begin{tabular}{llll}
\hline Property & Concrete & PVC & Steel \\
\hline Density $\left(\mathrm{kg} / \mathrm{m}^{3}\right)$ & 1800 & 1400 & 7800 \\
Thermal conductivity $(\mathrm{W} / \mathrm{kg} / \mathrm{K})$ & 1.15 & 0.2 & 45 \\
Specific heat $(\mathrm{J} / \mathrm{kg} / \mathrm{K})$ & 1000 & 1470 & 505 \\
\hline
\end{tabular}




\section{Conclusions}

The earth-air heat exchangers are a promising and effective technology for space conditioning of buildings. It is a device which utilizes the heat capacity of the Earth effectively. The EAHE system, if properly designed, can be a feasible and economical option to replace conventional air-conditioning systems. EAHE systems can be used in Chandiggarh city throughout the year, either as a stand-alone system for small-scale cooling of buildings, or as a complimentary system to be used in tandem with conventional HVAC systems of the building. The only problem with the EAHE systems is that, due to the humid nature of the climate in the rainy season, condensation takes place within the pipes and damages the system. Therefore, in Chandigarh, EAHE can be used effectively from October end to mid-June, i.e., from monsoon ending to monsoon starting. When humidity starts to peak, EAHE can be used along with conventional cooling systems.

Competing interests

The authors declare that they have no competing interests.

\section{Authors' contributions}

JS and SKS contributed equally towards preparing manuscript and subsequent revision. Both the authors read and approved the final manuscript.

\section{Author details}

${ }^{1}$ PEC University of Technology, Chandīgarh, India. ${ }^{2}$ Research Scholar Sanjay Kumar Singh: Associate Professor Civil Engineering Department PEC University of Technology, Chandīgarh 160012, India.

Received: 2 March 2015 Accepted: 30 June 2015

Published online: 11 July 2015

\section{References}

Bansal V, Misra R, Agrawal GD, Mathur J (2009) Performance analysis of earth-pipe-air heat exchanger for winter heating. Energy and Buildings 41(11):1151-1154

Bansal V, Misra R, Agrawal GD, Mathur J (2010) Performance analysis of earth-pipe-air heat exchanger for summer cooling. Energy and Buildings 42(5):645-648

Bansal V, Misra R, Agrawal GD, Mathur J (2012) Performance analysis of integrated earth-air-tunnel-evaporative cooling system in hot and dry climate. Energy and Buildings 47:525-532

Bhardwaj SS, Bansal NK (1981) Temperature distribution inside ground for various surface conditions. Build Environ 10(3):183-192

Bisoniya TS, Kumar A, Baredar P (2013) Experimental and analytical studies of earth-air heat exchanger (EAHE) systems in India: a review. Renew Sust Energ Rev 19:238-246

Bisoniya TS, Kumar A, Baredar P (2014) Cooling potential evaluation of earth-air heat exchanger system for summer season. Int J Eng Tech Res 2(4):309-316

Bisoniya TS, Kumar A, Baredar P (2015) Energy metrics of earth-air heat exchanger system for hot and dry climatic conditions of India. Energy and Buildings 86:214-221

Central Electricity Authority Load Generation Balance Report (2014-15). http://www.cea.nic.in/reports/yearly/ lgbr_report.pdf. Accessed 26 November 2014.

Chel A, Tiwari GN (2009) Performance evaluation and life cycle cost analysis of earth to air heat exchanger integrated with adobe building for New Delhi composite climate. Energy and Buildings 41:56-66

De Paepe M, Janssens A (2002) Thermo-hydraulic design of earth-air heat exchangers. Energy and Buildings 35:389-397

DMRC (2012) Geotechnical investigation for detailed project report for proposed phase-l of Chandigarh metro rail submitted to Chandigarh administration. Delhi Metro Rail Corporation, New Delhi

Ghosal MK, Tiwari GN (2004) Mathematical modelling for greenhouse heating by using thermal curtain and geothermal energy. Sol Energy 76(5):603-613

Goswami D, Dhaliwal A (1985) Heat transfer analysis in environmental control using an underground air tunnel. J Sol Energy Eng 107:141-145

IEA, Promoting energy efficiency investments (2008) http://www.iea.org/publications/freenew Desc.asp<PUBS ID=2009

Jacovides CP, Mihalakakou G, Santamouris M, Lewis JO (1996) On the ground temperature profile for passive cooling applications in building. Sol Energy 57(3):167-175

Jakhar S, Misra R, Bansal V, Soni MS (2015) Thermal performance investigation of earth air tunnel heat exchanger coupled with a solar air heating duct for northwestern India. Energy and Buildings 87:360-369

Kumar R, Kaushik SC, Garg SN (2006) Heating and cooling potential of an earth-to-air heat exchanger using artificial neural network. Renew Energy 31(80):1139-1155

Kusuda T (1975) The effect of ground cover on earth temperature. Proc. Conf. on Alternatives in Energy Conservation, the Use of Earth-Covered Buildings, Forth Worth, Texas, 9-12. 
Mihalakakou G (1997) On the application of the energy balance equation to predict ground temperature profiles. ASME- J Sol Energy Eng 60:181-190

Mihalakakou G, Santamouris M, Askimakopoulos D, Argiriou A (1995) On the ground temperature below buildings ASME- J. Sol Energy Eng 55:355-362

Official website of the Chandigarh Administration (2015). www.chandigarh.gov.in Accessed on 12 January 2015

Ozgener $L$ (2011) A review on the experimental and analytical analysis of earth to air heat exchanger (EAHE) systems in Turkey. Renew Sust Energ Rev 15(9):4483-4490

Ozgener O, Ozgener L (2010) Exergoeconomic analysis of an underground air tunnel system for greenhouse cooling system. Int J Refrig 33(5):995-1005

Ozgener O, Ozgener L (2011) Determining the optimal design of a closed loop earth to air heat exchanger for greenhouse heating by using exergoeconomics. Energy Build 43(4):960-965

Ozgener O, Ozgener L, Tester JW (2013) A practical approach to predict soil temperature variations for geothermal (ground) heat exchangers applications. Int J Heat Mass Transf 62:473-480

Parsons RA, ASHRAE (2000) HVAC systems and equipment handbook. Atlanta, GA

Perez-Lombard L, Ortiz J, Pout C (2008) A review on buildings energy consumption information. Energy and Buildings 40:394-398

Santamouris M, Mihalakakou G, Argiriou A, Asimakopoulos DN (1995) On the performance of buildings coupled with earth to air heat exchangers. Sol Energy 54(6):375-380

Sharan G, Jadhav R (2002) Soil temperature regime at Ahmedabad. J Agri Eng 39 (1): January-March 2002.

Sharan G, Jadhav R (2003) Performance of single pass earth-tube heat exchanger: an experimental study. J Agri Eng $40: 1-8$

Sugathan N, Biju V, Renuka G (2014) Influence of soil moisture content on surface albedo and soil thermal parameters at a tropical station. J Earth Syst Sci 125(5):1115-1128

Submit your manuscript to a SpringerOpen ${ }^{\circ}$ journal and benefit from:

- Convenient online submission

- Rigorous peer review

- Immediate publication on acceptance

- Open access: articles freely available online

- High visibility within the field

- Retaining the copyright to your article

Submit your next manuscript at $\gg$ springeropen.com 